Arq. Bras. Med. Vet. Zootec., v.66, n.2, p.617-620, 2014

\title{
Communication
}

[Comunicação]

\section{Anti-Escherichia coli activity of Brazilian plant extracts. New trends in Veterinary research}

\author{
[Atividade anti-Escherichia coli de extratos de plantas brasileiras. Novas \\ tendências em pesquisa veterinária]
}

L.R.P. Camargo, I.B. Suffredini*

Universidade Paulista - UNIP - São Paulo, SP

Escherichia coli is a widely known infective Gram negative bacteria found in the intestine of hot blood animals. Most E. coli strains are lowvirulent, however they may cause opportunistic infections in individuals, particularly in immunossuppressed, malnourished, new-born and elderly ones, when they are exposed to a focus of infection (Markey et al., 2005). Livestock, wild animals and pets are constantly exposed to $E$. coli, causing emotional disorder and economic loss to the owners (Carlton and McGavin, 1998). Moreover, E. coli strains showing resistance to commonly used antibiotics were isolated from wild animals (Carvalho et al., 2012), and demonstrate the impact of chemicals in the nature. An up-to-date issue highlights the use of plants in substitution to wide-used antibiotics (Avancini et al., 2000; Wiest et al., 2009).

Research aiming the identification of new antibiotics from nature is traditionally developed around the world and a wide range of chemicals have been isolated, identified and approved by important organs as Food and Drug Administration-USA (Newman and Cragg, 2012). Brazil is a rich country, in terms of its biodiversity (Azevedo, 2003). For that reason, a program aiming the identification of plant extracts that may provide new chemical compounds to be used as antibiotics to animals was established. So, 1,791 plant extracts were tested for their antibacterial activity against Escherichia coli ATCC 25922, using classical

Recebido em 16 de agosto de 2012

Aceito em 16 de outubro de 2013

*Autor para correspondência (corresponding author)

E-mail: ibsuffredini@yahoo.com.br antibacterial assays, as microdilution broth and disk diffusion assays.

Plants were collected in the Amazon rain forest (under license of Brazilian Government (12a/2008), IBAMA/MMA and CGEN/MMA) and were dried in air-circulating incubator, ground in a hammer-mill and $24 \mathrm{~h}$ macerated with a mixture of dichloromethane and methanol (1:1), followed by a $24 \mathrm{~h}$ maceration with water. Solvents were removed under vacuum and storage at $-20^{\circ} \mathrm{C}$ until use, so. Thus, an organic extract and an aqueous extract were obtained from each plant material. Dry extracts were ressuspended in 50\% dimethylsulfoxide and aqueous extracts in distilled water, at a concentration of $200 \mathrm{mg} / \mathrm{mL}$ (Suffredini et al., 2006a). Antibacterial assays were carried out under sterile conditions, described as follows.

Disk diffusion assay (DDA) was performed to identify antibacterial extracts. Mueller Hinton Agar (MHA) was prepared according to the manufacturer, and it was used to bacteria growth and maintenance. Escherichia coli ATCC 25922, was inoculated onto MHA at a concentration corresponding to 0.5 McFarland standards (Suffredini et al., 2004). Sterile paper discs measuring $6 \mathrm{~mm}$ diameter were equally distributed on the agar surface, and $10 \mu \mathrm{L}$ of each extract were added to a single paper disc. Chlorhexidine (CHX) $0.12 \%, 1 \%$ and $2 \%$ were used as standard drugs. Petri dishes were taken to incubator at $36^{\circ} \mathrm{C}$, for $24 \mathrm{~h}$. After that period, the presence of growth inhibition zone was observed. The active extracts were re-tested in 
triplicate, in order to confirm antibacterial activity, and growth inhibition zones were measured with a caliper rule. One-way ANOVA and Tukey's multiple comparison test were used to analyze differences among means $(\mathrm{P}<0.05)$, in DDA (GraphPad Prism 5.0).

The selected active extracts were tested in microdilution assay (MDBC), in order to have their minimal inhibitory and minimal bactericidal concentrations (MIC and MBC) determined. Mueller-Hinton broth (MHB) was prepared according to the manufacturer, in sterile conditions. Fresh colonies of Escherichia coli ATCC25922 were used to prepare a bacterial suspension corresponding to 0.5 McFarland standards. So, $190 \mu \mathrm{L}$ of the suspension were distributed in the wells of a round-bottom 96 well-microplate. Ten $\mu \mathrm{L}$ of different concentrations of extracts/standard drugs were added to the wells in duplicates, and the microplates were incubated at $37^{\circ} \mathrm{C}$, for $24 \mathrm{~h}$. Chlorhexidine $0.12 \%, 1 \%$ and $2 \%$ were used as standard drugs. After that period, the presence or absence of turbidity was observed for each well. All wells were subcultured in order to have MIC (the lowest concentrations that had shown a lack of turbidity, but bacteria growth in subculture) and MBC established (the lowest concentrations that had shown a lack of turbidity, and no bacteria growth in subculture) (Suffredini et al., 2006b).

Four out of 1,791 plant extracts showed a significant anti-Escherichia coli activity in DDA (Tab.1): EB 127 (obtained from Microplumeria anomala, Apocynaceae), EB 272 (obtained from
Casearia spruceana, Flacourtiaceae), EB 725 (obtained from Buchenavia sp., Combretaceae) and EB934 (obtained from Caryocar var. microcarpum, Caryocaraceae). Differences among growth inhibition zones (Tab. 2) originated from four extracts (EB 127, EB 272, EB 725 and EB 934) and three standard drugs (CHX 0.12\%, CHX 1\% and CHX 2\%) were significant $\left(\mathrm{F}_{(6,41)}=330.1 ; X^{2}=0.9826 ; \mathrm{p}<0.0001\right)$. EB 127, EB 272 and EB 725 showed to be less active than $\mathrm{CHX} 1 \%$ and $2 \%$, but showed a significant activity when compared to $\mathrm{CHX}$ $0.12 \% \quad(\mathrm{P}<0.001)$. Extract EB 934 showed an extremely significant activity in relation to $\mathrm{CHX}$ $0.12 \%$ and $1 \%(\mathrm{P}<0.001)$, and a similar activity if compared to CHX $2 \%(\mathrm{P}>0.05)$.

In the present report, it was observed that most of the studied plants did not show antibacterial activity, but only four out of 1,791 plant extracts. According to our experience, plants are more likely to be effective against Gram positive bacteria, such as Staphylococcus aureus, Enterococcus faecalis or Streptococcus spp than against Gram negative ones, such as Escherichia coli. Results show that all four extracts are likely to be tested in further antibacterial and toxicological assays, and are going to be chemically studied, in order to track for major active compounds. Both DDA and MDBC results show that EB 934 is the most promising extract, while the other three extracts showed a similar level of activity, barely compared to those observed for $\mathrm{CHX} 1 \%$ and $\mathrm{CHX} 2 \%$. Further work is being carried out in this direction.

Table 1. Botanical information relative to the plant extracts that showed significant antibacterial activity against Escherichia coli ATCC 25922

\begin{tabular}{cllc}
\hline Collection number & \multicolumn{1}{c}{ Family } & \multicolumn{1}{c}{ Species } & Extract number \\
\hline PSC 136 & Apocynaceae & Microplumeria anômala & EB 127 \\
AAO 3330 & Flacourtiaceae & Casearia spruceana & EB 272 \\
AAO 3379 & Combretaceae & Buchenavia sp. & EB 725 \\
AAO 3505 & Caryocaraceae & Caryocar cf. microcarpum & EB 934 \\
\hline
\end{tabular}


Anti-Escherichia coli activity...

Table 2. Results obtained from the disk diffusion assay carried out with for extracts (EB 127, EB 272, EB 725 and EB 934) and three standard drugs (CHX 0.12\%, CHX 1\% and CHX 2\%) against Escherichia coli ATCC 25922

\begin{tabular}{lccccccc}
\hline & EB 127 & EB 272 & EB 725 & EB 934 & CHX0.12\% & CHX1\% & CHX2\% \\
\hline Minimum & 7.000 & 7.000 & 7.000 & 13.85 & 0.0 & 11.00 & 12.35 \\
25\% Percentile & 7.263 & 7.225 & 7.300 & 13.85 & 0.0 & 11.30 & 12.61 \\
Median & 7.975 & 7.600 & 7.650 & 13.95 & 0.0 & 11.88 & 13.00 \\
75\% Percentile & 8.750 & 8.000 & 8.438 & 14.08 & 0.0 & 12.25 & 14.96 \\
Maximum & 8.900 & 8.000 & 8.550 & 14.30 & 0.0 & 13.00 & 15.00 \\
& & & & & & & \\
Mean & 7.983 & 7.583 & 7.775 & 13.98 & 0.0 & 11.86 & 13.50 \\
Std. Deviation & 0.7380 & 0.4355 & 0.5973 & 0.1693 & 0.0 & 0.6785 & 1.167 \\
Std. Error & 0.3013 & 0.1778 & 0.2438 & 0.06912 & 0.0 & 0.2770 & 0.4766 \\
& & & & & & & \\
Lower 95\% CI & 7.209 & 7.126 & 7.148 & 13.81 & 0.0 & 11.15 & 12.27 \\
Upper 95\% CI & 8.758 & 8.040 & 8.402 & 14.16 & 0.0 & 12.57 & 14.73 \\
\hline
\end{tabular}

MIC and MBC related to the four extracts were assessed. EB 127, obtained from Microplumeria sp. showed MIC and $\mathrm{MBC} \geq 700 \mathrm{mg} / \mathrm{mL}$; EB 272, obtained from Casearia sp., showed $\mathrm{MIC}=\mathrm{MBC}=600 \mathrm{mg} / \mathrm{mL}$; EB 725, obtained from Buchenavia sp., showed $\mathrm{MIC}=\mathrm{MBC} \leq 400 \mathrm{mg} / \mathrm{mL}$; and $\mathrm{EB} 934$, obtained from Caryocar sp., presented $400 \mathrm{mg} / \mathrm{mL}<\mathrm{MIC}<700 \mathrm{mg} / \mathrm{mL}$.

One-way ANOVA and Tukey's multiple comparison test were used to analyze differences among means $(\mathrm{p}<0.05)$

The present study showed the first steps into the discovery of new chemicals obtained from the Brazilian Amazon rain forest to fight infectious diseases of animals. The four active extracts here identified as showing activity against Escherichia coli were never studied before, in terms of its biological or chemical profiles. The present results will support our future work aiming the evaluation of the anti- Escherichia coli activity of the four active plant extracts against clinical isolate Escherichia coli strains, obtained from wild animals.

Keywords: Escherichia coli, plant extracts, pathogenicity

\section{RESUMO}

Escherichia coli é uma bactéria presente no trato intestinal de animais de sangue quente. Entretanto, a perda do equilibrio em sua relação com o hospedeiro pode causar doenças que levam a perdas economicas, quando se trata de animais de produção, e perdas incalculáveis, quando se trata de animais silvestres. $O$ presente estudo testou diversos extratos aquosos e orgânicos, obtidos de plantas da Amazônia brasileira, contra Escherichia coli (ATCC 25922). Usando o ensaio de disco difusão em ágar Mueller-Hinton (DDA), foram testados 1.791 extratos quanto à sua atividade antibacteriana. Os extratos que mostraram halo de inibição de crescimento bacteriano foram testados no modelo da microdiluição em caldo (MDBC) contra uma suspensão bacteriana preparada na escala de 0,5 McFarland para determinação da concentração inibitória mínima (CIM) e concentração bactericida mínima (CBM). Dois extratos orgânicos (EB 127 e EB725) e dois extratos aquosos (EB 272 e EB 934) testados inibiram o crescimento bacteriano no modelo DDA. O extrato orgânico EB127, obtido de Microplumeria sp., apresentou CIM e CBM $\geq 700 \mathrm{mg} / \mathrm{mL}$; o extrato aquoso EB272, obtido de Casearia $s p$., apresentou $C I M=C B M=600 \mathrm{mg} / \mathrm{mL}$; o extrato orgânico EB725, obtido de Buchenavia $s p$., apresentou $C I M=C B M \leq 400 \mathrm{mg} / \mathrm{mL}$; e o extrato aquoso EB934, obtido de Caryocar sp., apresentou $400 \mathrm{mg} / \mathrm{mL}<M I C<700 \mathrm{mg} / \mathrm{mL}$. Os extratos ativos apresentaram potencial para serem utilizados como antibióticos de uso veterinário, em animais acometidos por infecções causadas por E. coli. Embora um passo importante tenha sido dado para o desenvolvimento de novos fármacos de uso veterinário, é fundamental que estudos referentes à atividade farmacológica, toxicológica e a composição química dessas espécies sejam executados em um futuro próximo.

Palavras-chave: Escherichia coli, extratos vegetais, patogenicidade 


\section{ACKNOWLEDGEMENTS}

The authors want to thank FAPESP for support (grants \# 2008/58706-8 and 2010/09694-7).

\section{REFERENCES}

AVANCINI, C.A.M.; WIEST, J.M.; MINDSTOCK, E. Atividade bacteriostática e bactericida do decocto de Baccharis trimera (Less.) D.C., Compositae, carqueja, como desinfetante ou anti-séptico. Arq. Bras. Med. Vet. Zootec., v.52, p.230-234, 2000.

AZEVEDO, C.M.A. Bioprospecção: Coleta de Material Biológico com a Finalidade de Expor os Recursos Genéticos. Reserva da Biodiversidade da Mata Atlântica-MABUNESCO. 2.ed. São Paulo, cad. 17, mar. 2003, p.35. Available at: <http://www.semarh.pb. gov.br/comites/rbma/pdf/cad17.pdf >. Accessed in: $02 / 25 / 2010$.

CARLTON, W.W.; McGAVIN, M.D. Patologia Veterinária Especial de Thomson. 2.ed. Porto Alegre: Artmed, 1998. 67p.

CARVALHO, V.M.; OSUGUI, L.; SETZER, A.P. et al. Characterization of extraintestinal pathogenic Escherichia coli isolated from captive wild felids with bacteremia. J. Vet. Diag. Invest., v.24, p.1014-1016, 2012.
MARKEY, B.K.; CARTER, M.E.; DONNELY, W.J. Microbiologia Veterinária e Doenças Infecciosas, Porto Alegre: Artmed, 2005. p.512.

NEWMAN， D.J.; CRAGG， G.M. Natural products as sources of new drugs over the 30 years from 1981 to 2010. J. Nat. Prod., v.75, p.311-35, 2012.

SUFFREDINI, I.B.; PACIENCIA, M.L.B.; VARELLA, A.D.; YOUNES, R.N. In vitro prostate cancer cell growth inhibition by Brazilian plant extracts. Pharmazie, v.61, p.72224, 2006a.

SUFFREDINI, I.B.; PACIENCIA, M.L.B.; VARELLA, A.D.; YOUNES, R.N. Antibacterial activity of Brazilian Amazon plant extracts. Braz. J. Infect. Dis., v.10, p.400-402, 2006b.

SUFFREDINI, I.B.; SADER, H.S.; GONÇALVES, A.G. et al. Screening of antibacterial active extracts obtained from plants native to Brazilian Amazon rain forest and Atlantic forest. Braz. J. Med. Biol. Res., v.37, p.379-384, 2004.

WIEST, J.M.; CARVALHO, H.H.C.; AVANCINI, C.A.M.; GONÇALVES, A.R. Inibição e inativação in vitro de Salmonella spp. Com extratos de plantas com indicativo etnográfico medicinal ou condimentar. Arq. Bras. Med. Vet. Zootec., v.61, p.119-127, 2009. 